\title{
Incidence and risk factors for community-acquired acute gastroenteritis in north-west Germany in 2004
}

\author{
C. Karsten - S. Baumgarte - A. W. Friedrich • \\ C. von Eiff • K. Becker • W. Wosniok • A. Ammon • \\ J. Bockemühl $\cdot$ H. Karch $\cdot$ H.-I. Huppertz
}

Received: 19 November 2008 / Accepted: 5 March 2009/Published online: 25 March 2009

(C) The Author(s) 2009. This article is published with open access at Springerlink.com

\begin{abstract}
In developed countries, acute gastroenteritis (AGE) is a major source of morbidity. However, only a few studies have estimated its incidence and the associated medical burden. This population-based study determined the incidence of community-acquired AGE patients seeking medical care and the relative role of various pathogens. Stool samples from patients with AGE presenting to a general practitioner (GP), pediatrician, or specialist in internal medicine for that reason were screened for various bacterial and viral enteropath-
\end{abstract}

C. Karsten $\cdot$ H.-I. Huppertz $(\bowtie)$

Children's Hospital Prof. Hess, Klinikum-Bremen-Mitte,

Sankt-Jürgen-Straße,

28177 Bremen, Germany

e-mail: hans-iko.huppertz@klinikum-bremen-mitte.de

S. Baumgarte $\cdot$ J. Bockemühl

Institute for Hygiene and Environment,

Hamburg, Germany

A. W. Friedrich $\cdot$ H. Karch

Institute for Hygiene, University of Münster,

Münster, Germany

C. von Eiff $\cdot$ K. Becker

Institute of Medical Microbiology, University of Münster,

Münster, Germany

W. Wosniok

Institute for Statistics, University of Bremen,

Bremen, Germany

\author{
A. Ammon \\ Robert Koch Institute, \\ Berlin, Germany \\ H.-I. Huppertz \\ University of Göttingen, \\ Göttingen, Germany
}

ogens. A control group was established as well. Incidences were calculated by the number of positive patients divided by the general population. The study was performed in north-west Germany in 2004. The incidence of AGE patients requiring medical consultation was 4,020/100,000 inhabitants. Children $(<5$ years of age) were at the highest risk $(13,810 / 100,000$ inhabitants). Of the patients, $6.6 \%$ were tested positive for an enteropathogenic bacteria and $17.7 \%$ for a viral agent. The predominant pathogens were norovirus $(626 / 100,000)$ and rotavirus $(270 / 100,000)$. Salmonella was the most frequently detected bacteria $(162 / 100,000)$. The results presented confirm AGE and, specifically, AGE of viral origin as a major public health burden in developed countries.

\section{Introduction}

Acute gastroenteritis (AGE) characterized by vomiting, diarrhea, and dehydration is prevalent worldwide and is associated with high rates of mortality in developing countries [1, 2]. In more developed regions, AGE is a frequent cause of hospitalization, especially in young children [3].

Epidemiological studies from several European countries provide data on the incidence of AGE, risk factors, and the associated health burden [4-12]. German studies focused on young children [13, 14], while data on primary care consultations across all ages is lacking.. Findings are likely to differ between European countries due to nutritional habits, health behavior of the population, and differently set up health services $[4,7,8]$. The incidence of AGE cases presenting to general practice was reported to be $800 / 100,000$ inhabitants per year in The 
Netherlands and 3,300/100,000 inhabitants per year in England $[4,7]$. .

To reduce the incidence of AGE on a national and European level, changes were made to cattle and poultry breeding practices and the population was informed about hygienic measures over the last two decades. These measures significantly reduced the incidence of salmonellosis $[15,16]$ and most likely contributed to a shift in the relative contribution of pathogens that are currently causing AGE. Therefore, data demonstrating the relative importance of different viral, bacterial, and parasitic agents in causing AGE does need continuous updates since the distribution and relative importance of pathogens are likely to change over time. Moreover, the relevance of risk factors may be subject to change as well.

Nowadays, viral AGE is more frequently acknowledged, due partly to improved diagnostic methods and new virus variants, e.g., norovirus subtypes showing epidemic spread, as well as an increase in the number of outbreaks [17-19].

It has been acknowledged that persons may continue to excrete an enteropathogen after an episode of AGE or may even be an asymptomatic shedder without previous disease $[20,21]$. Asymptomatic carriers of viral or bacterial pathogens may have epidemiological importance due to their potency as a source of infection.

Various bacterial and viral enteropathogens are enclosed in the German surveillance system. However, studies from England and Ireland showed a systematic underreporting of AGE in national surveillance systems $[4,10]$. Incidences derived from surveillance systems are likely to be smaller than the incidences found in population-based studies.

The aims of the present study were to determine the incidence of community-acquired AGE cases presenting to general practice and to investigate the relative role of various bacterial and viral pathogens. Secondary aims were to identify risk factors for microorganism-specific AGE and determine the occurrence of asymptomatic carriers of viral or bacterial pathogens and multiple infections .

\section{Methods}

\section{Study population}

Between 1 January and 31 December 2004, all general practitioners (GPs) and specialists in pediatrics and internal medicine in an urban (suburbs of Bremen; 40,268 inhabitants) and rural area (Wesermarsch; 20,402 inhabitants) of Germany were asked to send stool samples from all patients presenting with AGE for laboratory investigation. In Germany, patients have free choice as to whether they consult a GP, pediatrician, or specialist in internal medicine. Forty-seven out of 67 physicians $(70 \%)$ registered in the study area participated actively and continuously in the study. The geographical and social conditions of these areas were considered to be particularly suitable for an epidemiological study: the urban area is separated from the rest of the city by the Weser River, while the rural area is limited by the North Sea and the broadening Weser River on three sides. It was expected that only very few patients would consult a physician outside of these study areas due to the special geographical conditions and accessibility of health care services.

Diarrhea was defined as the excretion of at least two loose and malodorous stools in breastfed infants and at least two loose stools in a 24-h period for all other patients [22]. Patients diagnosed with inflammatory bowel disease, celiac disease, cystic fibrosis, food intolerance, and malignancy were excluded from participation, in addition to patients on antibiotics or chemotherapy at the time of presentation.

To establish a control group, physicians were asked to send stool specimens from patients living in the same study areas who presented with symptoms other than diarrhea and vomiting. Patients and controls were asked to complete a questionnaire about their recent exposure to other people with diarrhea or about the consumption of food including poultry, unpasteurized milk, or other. In addition, we asked for symptoms and the course of their illness.

Case data was de-duplicated to ensure that one individual case was not included twice after presentation to different doctors.

All patients and controls or their parents or guardians gave written informed consent for participation in this study. The study protocol and data handling were approved by the local ethics committee.

\section{Microbiological methods}

Stool specimens were analyzed for Campylobacter spp., Salmonella enterica serovars, Yersinia spp., Shigella spp., enterotoxin-producing Staphylococcus aureus (detection of the marker genes sea, seb, sec, sed, see, seg, seh, sei, sej [23, 24]), Clostridium difficile, Aeromonas spp., and Plesiomonas spp. All specimens were analyzed as follows: $1 \mathrm{~g}$ of stool was plated on a combination of Columbia blood agar, Endo agar, and selective agars (CIN agar for Yersinia spp., Önöz and Leifson agar for Salmonella and Shigella spp., Sorbitol-MacConkey [SMAC] and CTSMAC agar for Shiga toxin-producing E. coli, and Charcoal Cefoperazon Deoxycholate agar [CCDA] and selenite broth for the detection of Campylobacter spp.). The CCDA and selenite broth were incubated in microaerophilic conditions and bacterial growth was detected as described previously [25].

The detection of marker genes for enteropathogenic $E$. coli (EPEC), enteroinvasive E. coli (EIEC), enterotoxic $E$. 
coli (ETEC) [26], enteroaggregative E. coli (EaggEC) [27], and enterohaemorrhagic E. coli (EHEC) was performed as described previously [28].

Virus detection

Enzyme immunoassay (EIA) was used for the detection of rotavirus, astrovirus, and adenovirus. A total of $100 \mu \mathrm{l}$ of stool specimen was diluted in appropriate amounts of sample buffer included in the commercial kit (DakoCytomation Ltd., Cambridgeshire, UK). The IDEIA ${ }^{\mathrm{TM}}$ kit detects group A rotaviruses, while the adenovirus EIA detects all human adenovirus serotypes. The astrovirus EIA works with a genus-specific combination of monoclonal and polyclonal antibodies and a special amplification system.

Nested polymerase chain reaction (PCR) was used for the detection of noroviruses. A total of $50 \mu$ l of stool specimen was diluted in $200 \mu \mathrm{l}$ of phosphate buffered saline (PBS). Viral RNA was extracted by the Purescript Total RNA Isolation (Gentra Systems, Minneapolis, MN, USA) and GI and GII norovirus was detected by nested RTPCR, as previously reported [29].

\section{Statistics}

Laboratory findings and responses from questionnaires were entered into a Microsoft Access ${ }^{\mathrm{TM}}$ database. The data were analyzed in Microsoft Excel ${ }^{\mathrm{TM}}$, where incidences, 95\% confidence intervals $\left(\mathrm{CI}_{95}\right)$, and odds ratios $(\mathrm{OR})$ were calculated. Pathogen-specific incidences were calculated by the number of positive patients divided by the general population. For the calculation of incidences, data were taken from population census in Bremen and Lower Saxony (http://www.nls.niedersachsen.de and Statistisches Landesamt Bremen, data on file). The total population of the catchment areas was diminished by that part of the population served by the non-participating physicians. Incidences were adjusted for age using direct standardization based on the German age distribution data for 2003 (http://www.destatis.de); for patients who lived in the study area but consulted a physician elsewhere; and for patients who refused to participate in this study. These data were obtained from the local public health authorities (LPHA) (Gesundheitsamt Bremen and Gesundheitsamt Wesermarsch, Brake, data on file). For the calculation of rotavirus, adenovirus, and astrovirus incidences, it was assumed that insufficient stool quantity with subsequent non-examination of these viruses was independent of the presence of these viruses. Hence, the expected number of infections among the non-examined stool samples was derived from the percentage of positive stool samples found in the group of examined patients.
Logistic regression analysis was performed using SAS System, Release 9.1 (SAS Institute Inc., Cary, NC, USA) to determine the variables that were independently associated with the risk of AGE. Variables were selected in a stepwise backward manner (maximum likelihood), in which the least significant variable was excluded at each step. The agentspecific morbidity was calculated as the percentage of symptomatic patients out of the total number of study participants positive for that agent.

Qualitative variables were compared by the $\chi^{2}$ test or Fisher's exact test, as appropriate. Significance was defined as $P<0.05$ and high significance as $P<0.001$. The LPHA also supplied data on the occurrence of clusters (i.e., two or more cases of AGE caused by the same microbiological agents), which were identified by telephone investigationlaboratory tests were not requested. These additional cases identified by the LPHA were not included in the calculation of incidences and the analysis of risk factors.

\section{Results}

In total, 1,630 patients and controls were included in the analyses. Of these, 1,463 (90\%) returned a completed questionnaire. A total of 1,086 specimens were collected from patients with diarrhea, 639 in the urban area and 447 in the rural area. From the controls, 544 specimens were collected, 338 specimens in the urban area and 206 specimens in the rural area. The sex and age distribution of the study population is shown in Table 1 .

Due to insufficient stool quantities, some samples could not be tested for all viruses and bacteria. Out of 1,630 stool specimens, 1,580 (96.9\%) were tested for enteropathogenic bacteria, $1,585(97.2 \%)$ were tested for norovirus, and $1,338(82.1 \%)$ were tested for all four viral agents (Table 2).

Incidence of gastroenteritis

The overall incidence of AGE requiring medical consultation was 4,020/100,000 inhabitants $\left(\mathrm{CI}_{95}[1,879 ; 6,687]\right)$, with no significant difference between the urban and rural areas.

Children younger than five years of age had the highest incidence of AGE requiring medical consultation $\left(13,810 / 100,000 ; \mathrm{CI}_{95}[6,819 ; 21,601]\right)$, which was significantly different from the rest of the population $(P<$ $\left.0.001, \mathrm{OR}=3.88 ; \mathrm{CI}_{95}[3.3 ; 4.6]\right)$. In this age group, one out of six children consulted a physician due to AGE in the urban area $\left(15,967 / 100,000 ; \mathrm{CI}_{95}[7,979 ; 24,691]\right)$, in contrast to one out of ten children in the rural area $\left(10,791 / 100,000 ; \mathrm{CI}_{95}[5,230 ; 17,368]\right)$. This difference was significant $\left(P=0.008, \mathrm{OR}=1.57 ; \mathrm{CI}_{95}[1.1 ; 2.2]\right)$. 
Table 1 Demographic structure of patients and controls, shown as number of probands (percent)

\begin{tabular}{llllll}
\hline & \multicolumn{2}{l}{ Urban area } & & \multicolumn{2}{l}{ Rural area } \\
\cline { 2 - 3 } \cline { 6 - 7 } & Patients with diarrhea & Controls & & Patients with diarrhea & Controls \\
\hline Total & $639(100 \%)$ & $338(100 \%)$ & & $447(100 \%)$ & $206(100 \%)$ \\
Male & $308(48.2 \%)$ & $154(45.6 \%)$ & & $242(54.1 \%)$ & $88(42.7 \%)$ \\
Female & $331(51.8 \%)$ & $184(54.4 \%)$ & & $205(45.9 \%)$ & $118(57.3 \%)$ \\
Age $<5$ years & $76(11.9 \%)$ & $17(5.0 \%)$ & & $50(11.2 \%)$ & $8(3.9 \%)$ \\
$5-14$ years & $80(12.5 \%)$ & $58(17.2 \%)$ & & $98(21.9 \%)$ & $39(18.9 \%)$ \\
$15-59$ years & $362(56.7 \%)$ & $196(58.0 \%)$ & & $238(53.2 \%)$ & $83(40.3 \%)$ \\
$>59$ years & $121(18.9 \%)$ & $67(19.8 \%)$ & & $61(13.6 \%)$ & $76(36.9 \%)$ \\
\hline
\end{tabular}

Similarly, in people aged 60 years or older, there was a highly significant difference in incidences between the rural and urban areas $\left(P<0.001, \mathrm{OR}=2.41 ; \mathrm{CI}_{95}[1.8 ; 3.2]\right)$ (Table 3).

In the urban area, the highest incidences of medical consultations due to AGE were from October through to December, whereas in the rural area, the highest incidences were found in January, March, and April, which is coincident with the different pathogen patterns between the two areas

Incidence of specific viral and bacterial pathogens

A total of 80 out of 1,580 specimens tested positive for enteropathogenic bacteria (72 patients, 6.6\%, and eight controls, $1.5 \%$ ), while 320 out of 1,585 specimens tested positive for a viral agent (280 patients, $17.7 \%$, and 40 controls, 2.5\%). Overall, viral and bacterial pathogens were identified in $35 \%$ of specimens from patients with AGE (Table 2). Months with high incidences of viral pathogens revealed a higher portion of positive stool specimens than months that showed lower incidences of viral pathogens (Fig. 1).

Norovirus and rotavirus were the most frequently detected pathogens. Norovirus was found in $16 \%$ of all cases with AGE (Table 2). The incidence was 626/100,000 inhabitants $\left(\mathrm{CI}_{95}[287 ; 1,071]\right)$. Norovirus was detected all-year-round, with two peaks. The months with the highest incidences of norovirus infection were March and December in the rural area and November and December in the urban area. Morbidity for norovirus-related AGE was $89.2 \%$.

Rotavirus was responsible for 270 episodes/100,000 inhabitants $\left(\mathrm{CI}_{95}[124 ; 467]\right)$. The incidence of rotavirusrelated AGE in children younger than five years of age $\left(2,574 / 100,000, \mathrm{CI}_{95}[1,193 ; 4,455]\right)$ was higher than that for noroviruses in this age group $\left(2,302 / 100,000, \mathrm{CI}_{95}\right.$ $[1,065 ; 4,006])$, thus, confirming that rotavirus is the most important pathogen causing AGE in young children. Rotavirus-related AGE occurred all-year-round, with a distinctive seasonal peak in March and April. Morbidity for rotavirus-related AGE was 84.1\%.

Table 2 Detected microorganisms

\begin{tabular}{|c|c|c|c|c|c|}
\hline & \multicolumn{3}{|c|}{ Patients $(n=1,086)$} & \multicolumn{2}{|c|}{ Controls $(n=544)$} \\
\hline & Number tested & $\%$ positive & Incidence/100,000 inhabitants, [confidence interval] & Number tested & $\%$ positive \\
\hline Norovirus & 1,053 & 16 & $626[287 ; 1,071]$ & 532 & 3.4 \\
\hline Rotavirus & 875 & 7 & $270[124 ; 467]$ & 464 & 2.8 \\
\hline Astrovirus & 875 & 3 & $111[51 ; 196]$ & 464 & 1.7 \\
\hline Adenovirus & 875 & 2.9 & $113[52 ; 199]$ & 464 & 0.2 \\
\hline Salmonella & 1,046 & 2 & $162[74 ; 290]$ & 534 & 0 \\
\hline Campylobacter spp. & 1,046 & 1.2 & $55[25 ; 101]$ & 534 & 0 \\
\hline Yersinia enterocolitica & 1,046 & 0.9 & $34[16 ; 65]$ & 534 & 0 \\
\hline Plesiomonas & 1,046 & 0.1 & Not calculated & 534 & 0 \\
\hline Aeromonas spp. & 1,046 & 0.7 & $31[14 ; 58]$ & 534 & 0.4 \\
\hline EPEC & 1,046 & 0.3 & Not calculated & 534 & 0.6 \\
\hline Enterotoxin-encoding $S$. aureus & 1,046 & 1.7 & $67[31 ; 120]$ & 534 & 0.6 \\
\hline No enteropathogen found & \multicolumn{3}{|l|}{$709(65 \%)$} & \multicolumn{2}{|l|}{$484(89 \%)$} \\
\hline
\end{tabular}


Table 3 Incidence of AGE per 100,000 inhabitants in different age groups in the study areas

\begin{tabular}{llll}
\hline Age groups & Rural area & Urban area & $P$-value, OR, CI ${ }_{95}$ \\
\hline$<5$ years & $10,791[5,230 ; 17,368]$ & $15,967[7,979 ; 24,691]$ & $0.008,1.57[1.1 ; 2.2]$ \\
$5-19$ years & $4,177[1,953 ; 7,010]$ & $5,178[2,435 ; 8,611]$ & $0.15,1.24[0.9 ; 1.6]$ \\
$20-59$ years & $4,070[1,902 ; 6,789]$ & $2,806[1,303 ; 4,718]$ & $0.001,0.76[0.6 ; 0.9]$ \\
$>60$ years & $2,421[1,121 ; 4,131]$ & $5,321[2,504 ; 8,813]$ & $<0.001,2.41[1.8 ; 3.2]$
\end{tabular}

Incidences of AGE due to astroviruses and adenoviruses are shown in Table 2. Children younger than five years were at the highest risk, but astroviruses were an important agent for viral AGE in all age groups. Adenoviruses were rarely detected in patients aged five years or older.

Salmonella was the most frequently detected bacteria found in patients with $\operatorname{AGE}\left(162 / 100,000, \mathrm{CI}_{95}[74 ; 290]\right)$, followed by enterotoxin gene-carrying S. aureus $(67 / 100,000$, $\left.\mathrm{CI}_{95}[31 ; 120]\right)$ and Campylobacter spp. $\left(55 / 100,000, \mathrm{CI}_{95}\right.$ $[25 ; 101])$. The age groups with the highest incidences of all of these bacterial agents were children aged 0-14 years. Salmonella infections showed a typical seasonal distribution, prevailing between May and October. Salmonella and Campylobacter spp. showed 100\% morbidity.

Aeromonas spp. and $Y$. enterocolitica had comparable incidences. Plesiomonas spp. and EPEC were found in one and three cases, respectively (Table 2). EaggEC, EHEC, EIEC, ETEC, or Shigella spp. were not isolated.

A total of 34 positive stool specimens from patients were carrying two or more infectious agents (Table 4). In controls, no co-infections were detected.

Table 5 shows the typical symptoms of AGE caused by the various viral (frequently vomiting) and bacterial (frequently fever) enteropathogens. Table 6 shows the risk factors for acquiring AGE.

\section{Discussion}

This is the first population-based study presenting the incidence of community-acquired AGE requiring medical

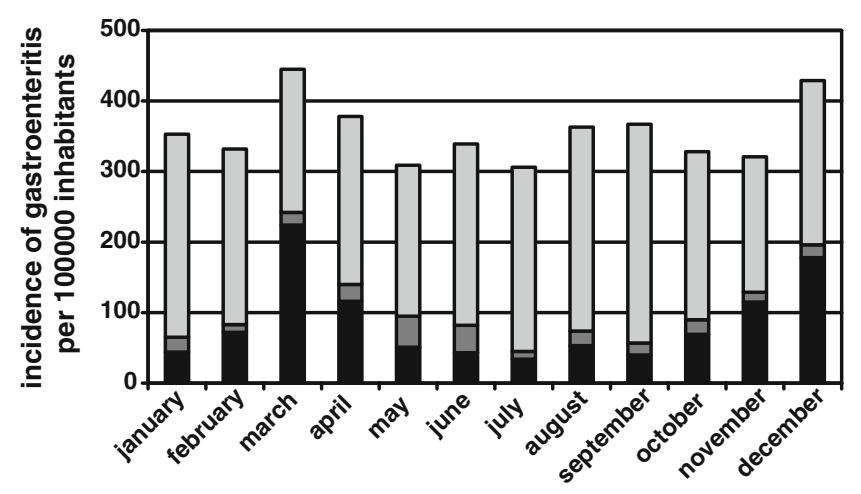

uviral pathogen abacterial pathogen $u$ no proof of pathogen

Fig. 1 Monthly distribution of pathogens consultation across all age groups within defined areas over a complete year. This study shows that AGE is a very frequent disease, with children aged $0-4$ years particularly at risk. Viral and/or bacterial pathogens were detected in $35 \%$ of specimens from patients with AGE. Viral pathogens were detected far more often than bacterial pathogens.

We believe that these results might be representative for most of Germany and even other European countries.

Four percent of the study population consulted a physician due to diarrhea in $2004(4,020 / 100,000)$. This incidence is higher than that reported by Wheeler et al. in England (3,300/100,000 inhabitants) [4]. Furthermore, it is almost five times higher than the incidence reported by de Wit et al. in The Netherlands $(800 / 100,000)$ [7]. It is possible that the guidelines of the Dutch College of General Practitioners (NHG) - which state that patients with an uncomplicated case of AGE can be dealt with by phone consultation (http://nhg.artsennet.nl) - may dissuade patients from seeking medical assistance and, thus, explain the low incidence of AGE found in The Netherlands. Slightly different case definitions between the studies may be another explanation for the varying incidences.

The incidence of AGE reported in this study proves it to be a major public health burden and suggests that AGE may have important cost implications for the healthcare system. Information about the magnitude of the public health burden of AGE is urgently needed in Germany.

Tam et al. [30] described risk factors associated with presentation to a GP in patients with infectious intestinal diseases. They suggest how these risk factors may introduce selection bias when performing a case-control study using

Table 4 Co-infections

\begin{tabular}{ll}
\hline Combination of infectious agents & No. \\
\hline Norovirus and rotavirus & 10 \\
Norovirus and enterotoxin-encoding S. aureus & 5 \\
Norovirus and astrovirus & 4 \\
Norovirus and Salmonella & 3 \\
Rotavirus and adenovirus & 2 \\
Astrovirus and rotavirus, norovirus and Campylobacter coli, & 1 \\
astrovirus and S. aureus, rotavirus and S. aureus, rotavirus and & \\
Aeromonas spp., norovirus and Aeromonas spp., rotavirus and & \\
Salmonella, Y. enterocolitica and Salmonella, Y. enterocolitica & \\
$\quad$ and enteropathogenic Escherichia coli & \\
Norovirus, astrovirus and S. aureus & 1 \\
\hline
\end{tabular}


Table 5 Self-reported symptoms of patients

\begin{tabular}{|c|c|c|c|c|c|c|c|c|}
\hline Self-reported symptoms & $\begin{array}{l}\text { Norovirus } \\
(n=168)\end{array}$ & $\begin{array}{l}\text { Rotavirus } \\
(n=61)\end{array}$ & $\begin{array}{l}\text { Astrovirus } \\
(n=26)\end{array}$ & $\begin{array}{l}\text { Adenovirus } \\
(n=25)\end{array}$ & $\begin{array}{l}\text { Salmonella } \\
(n=21)\end{array}$ & $\begin{array}{l}\text { Campylobacter } \\
\text { spp. }(n=13)\end{array}$ & $\begin{array}{l}\text { Yersinia } \\
\text { enterocolitica } \\
(n=9)\end{array}$ & $\begin{array}{l}\text { S. aureus } \\
(n=28)\end{array}$ \\
\hline & $\%$ & $\%$ & $\%$ & $\%$ & $\%$ & $\%$ & $\%$ & $\%$ \\
\hline Watery stool & 75.4 & 65.6 & 47.0 & 42.1 & 68.8 & 63.4 & 37.0 & 55.6 \\
\hline Loose stool & 43.7 & 54.6 & 42.7 & 38.3 & 31.7 & 17.1 & 61.7 & 61.7 \\
\hline Bloody stool & 0.7 & 0 & 0 & 3.8 & 5.3 & 8.5 & 12.3 & 18.5 \\
\hline Abdominal pain & 37.7 & 32.8 & 51.3 & 30.7 & 10.6 & 17.1 & 49.4 & 55.6 \\
\hline Loss of body weight & 37.7 & 41.9 & 51.3 & 88.1 & 5.3 & 59.8 & 12.3 & 30.9 \\
\hline Fever & 15.2 & 36.4 & 8.5 & 7.7 & 26.5 & 42.7 & 61.7 & 24.7 \\
\hline Fatigue & 25.2 & 21.9 & 17.0 & 3.8 & 0 & 8.5 & 24.7 & 18.5 \\
\hline \multirow[t]{2}{*}{ Vomiting } & 60.8 & 56.5 & 34.2 & 30.7 & 31.8 & 17.1 & 0 & 37.0 \\
\hline & Median & Median & Median & Median & Median & Median & Median & Median \\
\hline $\begin{array}{l}\text { Max. no. of bowel } \\
\text { evacuations per } 24 \mathrm{~h}\end{array}$ & 5 & 5 & 8 & 6 & 14.5 & 11 & 6 & 6 \\
\hline Additional symptoms ${ }^{\mathrm{a}}$ & $1-10$ & $2-5 ; 7-10$ & $2 ; 3 ; 5-7$ & $3 ; 10$ & 2 & none & $1-3$ & $1-3 ; 6 ; 8$ \\
\hline
\end{tabular}

${ }^{a}$ Additional symptoms: $1=$ arthralgia, $2=$ headache, $3=$ nausea, $4=$ vertigo, $5=$ dorsalgia, $6=$ heartburn, $7=$ meteorism, $8=$ fever chills, $9=$ limb pain, $10=$ lack of appetite

Table 6 Factors associated with a higher risk for acquiring AGE based on multiple logistic regression $(P$-value, OR)

\begin{tabular}{|c|c|c|c|c|c|c|c|c|c|c|}
\hline & \multicolumn{3}{|c|}{ Age (years) } & \multirow[t]{2}{*}{$\begin{array}{l}\text { Rural } \\
\text { area }\end{array}$} & \multicolumn{3}{|c|}{ Contact within the last ten days } & \multicolumn{2}{|c|}{$\begin{array}{l}\text { Consumption of ... } \\
\text { within the last ten } \\
\text { days }\end{array}$} & \multirow[t]{2}{*}{$\begin{array}{l}\text { Journey abroad } \\
\text { within the last two } \\
\text { months }\end{array}$} \\
\hline & $<5$ & $5-15$ & $>59$ & & $\begin{array}{l}\text { With persons } \\
\text { with diarrhea }\end{array}$ & $\begin{array}{l}\text { With } \\
\text { animals }\end{array}$ & $\begin{array}{l}\text { With } \\
\text { cattle }\end{array}$ & Poultry & $\begin{array}{l}\text { Other } \\
\text { foods }\end{array}$ & \\
\hline \multirow[t]{2}{*}{ Diarrhea } & 0.02 & 0.009 & 0.01 & \multirow[t]{2}{*}{ n.s. } & $<0.001$ & \multirow[t]{2}{*}{ n.s. } & \multirow[t]{2}{*}{ n.s. } & 0.04 & $<0.001$ & 0.01 \\
\hline & 1.6 & 0.6 & 0.7 & & 1.9 & & & 1.3 & 5.2 & 1.8 \\
\hline \multirow[t]{2}{*}{ Norovirus } & \multirow[t]{2}{*}{ n.s. } & \multirow[t]{2}{*}{ n.s. } & 0.03 & \multirow[t]{2}{*}{ n.s. } & $<0.001$ & 0.03 & n.s. & n.s. & n.s. & n.s. \\
\hline & & & 1.6 & & 2.7 & 0.7 & & & & \\
\hline \multirow[t]{2}{*}{ Rotavirus } & $<0.001$ & \multirow[t]{2}{*}{ n.s. } & \multirow[t]{2}{*}{ n.s. } & 0.04 & 0.01 & \multirow[t]{2}{*}{ n.s. } & \multirow[t]{2}{*}{ n.s. } & \multirow[t]{2}{*}{ n.s. } & \multirow[t]{2}{*}{ n.s. } & \multirow[t]{2}{*}{ n.s. } \\
\hline & 4.4 & & & 1.8 & 2.1 & & & & & \\
\hline \multirow[t]{2}{*}{ Astrovirus } & \multirow[t]{2}{*}{ n.s. } & \multirow[t]{2}{*}{ n.s. } & \multirow[t]{2}{*}{ n.s. } & \multirow[t]{2}{*}{ n.s. } & 0.04 & \multirow[t]{2}{*}{ n.s. } & \multirow[t]{2}{*}{ n.s. } & \multirow[t]{2}{*}{ n.s. } & $0.006^{*}$ & \multirow[t]{2}{*}{ n.s. } \\
\hline & & & & & 2.3 & & & & 3.2 & \\
\hline \multirow[t]{2}{*}{ Campylobacter spp. } & \multirow[t]{2}{*}{ n.s. } & 0.03 & \multirow[t]{2}{*}{ n.s. } & 0.02 & n.s. & \multirow[t]{2}{*}{ n.s. } & \multirow[t]{2}{*}{ n.s. } & \multirow[t]{2}{*}{ n.s. } & $<0.001 * *$ & n.s. \\
\hline & & 4.2 & & 4.9 & & & & & 11.4 & \\
\hline Salmonella & $<0.001$ & $<0.001$ & n.s. & n.s. & n.s. & n.s. & n.s. & n.s. & $<0.001^{* * *}$ & n.s. \\
\hline & 8.8 & 16.3 & & & & & & & 7.8 & \\
\hline Enterotoxin gene- & n.s. & 0.01 & n.s. & n.s. & n.s. & n.s. & n.s. & n.s. & n.s. & n.s. \\
\hline & & 2.8 & & & & & & & & \\
\hline
\end{tabular}

The following variables were tested but not determined as significantly associated with the risk of infectious gastroenteritis due to any of the tested agents: gender, pets in the household, contact with poultry within the last ten days, contact with other domestic animals within the last ten days, consumption of unpasteurized milk within the last ten days

n.s.: not significant

*Fish, beef, pork, milk products, vegetables, fruit

**Milk products, beef, vegetables, fruit

***Eggs, egg products, milk 
this sub-set of patients only. GP presentation is associated with biological factors, such as disease severity, and social factors, such as educational level [30]. Some patients may not have seen a physician in spite of severe AGE, and some patients may have seen a physician in the presence of mild AGE. Wheeler et al. described that the ratio of community incidence to GP presentation incidence differs depending on the pathogen. Patients infected by Salmonella spp. were more likely to present to their GP than patients infected by rota- or norovirus [4]. Therefore, it is likely that the relative frequency of pathogens in patients may differ from the relative frequency of pathogens in the community.

Viral and bacterial pathogens were identified in about one third of the specimens. The proportion of positive samples is in agreement with the findings of Sinclair et al. and de Wit et al. [7, 8, 31]. There are several factors which might explain why no causative agent was detected in the remaining specimens. Organisms may have escaped detection due to the low numbers present in specimens, the delay between the onset of symptoms and collection of specimens, transport loss due to overgrowth by physiological stool flora, or better laboratory assays. In some cases, patients may have been infected by enteropathogens that were not included in the diagnostic scope-for instance, by parasites or rare viruses. Finally, diarrhea may occur as a symptom in non-infectious illnesses, although the majority of which were excluded by the study design. Further research is urgently needed to refine the methods used for the efficient detection of known causative agents of AGE and to discover as yet unknown pathogens.

Viral pathogens were detected more frequently than bacterial pathogens. This finding was independent from age, suggesting that viruses are the leading cause of AGE in all age groups. This finding suggests that it is not appropriate to perform diagnostic procedures on apparently sporadic cases of AGE for bacterial pathogens only. Of note, 34 stool specimens were tested positive for two or more viral and/or bacterial pathogens. Based on the clinical information available, it was not possible to determine if one of the pathogens or a combination were responsible for the diarrheal symptoms.

Rotavirus infections occurred significantly more often in children aged five years or younger than in adults, while norovirus infections occurred significantly more often in people aged 60 years or older. These findings are most likely explained by the fact that primary infection with rotavirus confers protective immunity against symptomatic rotavirus infection, with subsequent infections later in life remaining asymptomatic or associated with milder symptoms [32]. Knowledge on immunity to norovirus is incomplete [33, 34]. No vaccines against norovirus are available yet, while two vaccines against rotavirus are currently licensed in Europe [35-37]. Introducing a safe and effective vaccine against rotavirus will most likely reduce the morbidity and mortality of AGE considerably, especially in young children.

A pathogen was detected in 48 samples from controls. In these cases, viral pathogens were found more frequently than bacterial pathogens. After an episode of AGE, patients may continue to excrete the pathogen for variable periods. Patients may even be asymptomatic shedders without previous disease $[20,21]$. de Wit et al. described asymptomatic carriers of rotavirus, norovirus, adenovirus, and astrovirus in healthy controls [7]. This can have epidemiological importance due to their capacity to act as a source of infection, which is especially relevant for viral pathogens with high tenacity, low infective dose, and predominant person-to-person transmission. Asymptomatic shedders may be important vectors of these viruses into healthcare institutions, where the burden of outbreaks has risen over recent years [38].

In this study, close contact with persons who experienced diarrhea within the previous ten days was an important risk factor for acquiring viral AGE. This suggests that many cases were not sporadic but were part of outbreaks. For AGE, due to Salmonella and Campylobacter spp. a significant risk factor was the consumption of certain foods implicated by the patients.

Incidences of AGE caused by various viral and bacterial pathogens found in this study were 2.5-10 times higher than incidences based on reported cases within the German surveillance system (http://www.rki.de). The reported incidence of norovirus in 2004 was 77.1/100,000 inhabitants compared with $626 / 100,000$ inhabitants in this study. Findings for rotavirus (45.5 versus 270/100,000 inhabitants) and Salmonella (68.7 versus 162/100,000 inhabitants) confirmed the systematic underreporting in the surveillance system. Reasons for this are summarized in the concept of the AGE disease pyramid: only a fraction of community cases of AGE seek medical care and only a fraction of those will be requested to or will submit a stool sample for testing. Furthermore, only a fraction of stool samples will be tested positive for a causative agent, as has been reported in other countries with national surveillance systems [4, 10, 30, 39].

In conclusion, this population-based study on the incidence of community-acquired AGE showed a high disease burden and a marked underreporting of the disease and demonstrated a significant predominance of viral AGE throughout the year. This study leads the way for investigations to assess the full extent of AGE. Additional studies on the disease burden should follow.

Acknowledgments Dr. C. Karsten is a resident in pediatrics at the Children's Hospital Prof. Hess, Bremen, Germany. Her research interests include infectious diseases and public health. 
This study is supported by the Federal Ministry of Education and Research (Research Fund 01KI0205).

No author has any conflict of interest.

Aspects of this study have been presented at the 25th Annual Meeting of the European Society of Pediatric Infectious Diseases, Porto, Portugal, May 2007.

Open Access This article is distributed under the terms of the Creative Commons Attribution Noncommercial License which permits any noncommercial use, distribution, and reproduction in any medium, provided the original author(s) and source are credited.

\section{References}

1. O'Ryan M, Prado V, Pickering LK (2005) A millennium update on pediatric diarrheal illness in the developing world. Semin Pediatr Infect Dis 16:125-136. doi:10.1053/j.spid.2005.12.008

2. Parashar UD, Bresee JS, Glass RI (2003) The global burden of diarrhoeal disease in children. Bull World Health Organ 81:236

3. Lugauer S, Überall MA, Schmitt-Grohé S et al (2000) Inzidenz und Symptomatik von hospitalisierten Gastroenteritiden in einer Kohorte von 10.271 Säuglingen und Kleinkindern. Monatsschr Kinderheilkd 148:119-122. doi:10.1007/s001120050021

4. Wheeler JG, Sethi D, Cowden JM et al (1999) Study of infectious intestinal disease in England: rates in the community, presenting to general practice, and reported to national surveillance. The Infectious Intestinal Disease Study Executive. BMJ 318:1046-1050

5. van den Brandhof WE, De Wit GA, de Wit MA et al (2004) Costs of gastroenteritis in The Netherlands. Epidemiol Infect 132:211221. doi: $10.1017 / \mathrm{S} 0950268803001559$

6. Roberts JA, Cumberland P, Sockett PN et al (2003) The study of infectious intestinal disease in England: socio-economic impact. Epidemiol Infect 130:1-11. doi:10.1017/S0950268802007690

7. de Wit MA, Koopmans MP, Kortbeek LM et al (2001) Gastroenteritis in sentinel general practices, The Netherlands. Emerg Infect Dis 7:82-91

8. de Wit MA, Koopmans MP, Kortbeek LM et al (2001) Sensor, a population-based cohort study on gastroenteritis in the Netherlands: incidence and etiology. Am J Epidemiol 154:666-674. doi:10.1093/aje/154.7.666

9. Tompkins DS, Hudson MJ, Smith HR et al (1999) A study of infectious intestinal disease in England: microbiological findings in cases and controls. Commun Dis Public Health 2:108-113

10. Scallan E, Fitzgerald M, Collins C et al (2004) Acute gastroenteritis in northern Ireland and the Republic of Ireland: a telephone survey. Commun Dis Public Health 7(1):61-67

11. Kuusi M, Aavitsland P, Gondrosen B et al (2003) Incidence of gastroenteritis in Norway - a population-based survey. Epidemiol Infect 131(1):591-597. doi:10.1017/S0950268803008744

12. Gauci C, Gilles H, O'Brien S et al (2007) The magnitude and distribution of infectious intestinal disease in Malta: a populationbased study. Epidemiol Infect 135(8):1282-1289

13. Ehlken B, Laubereau B, Karmaus W et al (2002) Prospective population-based study on rotavirus disease in Germany. Acta Paediatr 91:769-775. doi:10.1080/08035250213227

14. van Damme P, Giaquinto C, Huet F et al (2007) Multicenter prospective study of the burden of rotavirus acute gastroenteritis in Europe, 2004-2005: the REVEAL study. J Infect Dis 195 (Suppl 1):4-16. doi:10.1086/516714

15. Ethelberg S, Olsen KE, Gerner-Smidt P et al (2004) Household outbreaks among culture-confirmed cases of bacterial gastrointestinal disease. Am J Epidemiol 159:406-412. doi:10.1093/aje/ kwh049
16. van Pelt W, de Wit MA, Wannet WJ et al (2003) Laboratory surveillance of bacterial gastroenteric pathogens in The Netherlands, 1991-2001. Epidemiol Infect 130:431-441

17. Lopman BA, Reacher M, Gallimore C et al (2003) A summertime peak of "winter vomiting disease": surveillance of noroviruses in England and Wales, 1995 to 2002. BMC Public Health 3:13. doi:10.1186/1471-2458-3-13

18. Lopman B, Vennema H, Kohli E et al (2004) Increase in viral gastroenteritis outbreaks in Europe and epidemic spread of new norovirus variant. Lancet 363:682-688. doi:10.1016/S0140-6736 (04)15641-9

19. van Duynhoven YT, de Jager CM, Kortbeek LM et al (2005) A one-year intensified study of outbreaks of gastroenteritis in The Netherlands. Epidemiol Infect 133:9-21. doi:10.1017/ S0950268804002936

20. Moore JE, Corcoran D, Dooley JS et al (2005) Campylobacter. Vet Res 36:351-382. doi:10.1051/vetres:2005012

21. Amieva MR (2005) Important bacterial gastrointestinal pathogens in children: a pathogenesis perspective. Pediatr Clin North Am 52:749-777. doi:10.1016/j.pcl.2005.03.002

22. Huppertz H-I, Busch D, Schmidt H et al (1996) Diarrhea in young children associated with Escherichia coli non-O157 organisms that produce Shiga-like toxin. J Pediatr 128:341-346. doi:10.1016/S0022-3476(96)70278-0

23. Becker K, Friedrich AW, Lubritz G et al (2003) Prevalence of genes encoding pyrogenic toxin superantigens and exfoliative toxins among strains of Staphylococcus aureus isolated from blood and nasal specimens. J Clin Microbiol 41:1434-1439. doi:10.1128/JCM.41.4.1434-1439.2003

24. Becker K, Roth R, Peters G (1998) Rapid and specific detection of toxigenic Staphylococcus aureus: use of two multiplex PCR enzyme immunoassays for amplification and hybridization of staphylococcal enterotoxin genes, exfoliative toxin genes, and toxic shock syndrome toxin 1 gene. J Clin Microbiol 36(9):25482553

25. Endtz HP, Ruijs GJ, Zwinderman AH et al (1991) Comparison of six media, including a semisolid agar, for the isolation of various Campylobacter species from stool specimens. J Clin Microbiol 29:1007-1010

26. Nataro JP, Kaper JB (1998) Diarrheagenic Escherichia coli. Clin Microbiol Rev 11:142-201

27. Huppertz HI, Rutkowski S, Aleksic S et al (1997) Acute and chronic diarrhoea and abdominal colic associated with enteroaggregative Escherichia coli in young children living in western Europe. Lancet 349:1660-1662. doi:10.1016/S0140-6736(96) 12485-5

28. Friedrich AW, Bielaszewska M, Zhang WL et al (2002) Escherichia coli harboring Shiga toxin 2 gene variants: frequency and association with clinical symptoms. J Infect Dis 185:74-84. doi:10.1086/338115

29. Oh DY, Gaedicke G, Schreier E (2003) Viral agents of acute gastroenteritis in German children: prevalence and molecular diversity. J Med Virol 71:82-93. doi:10.1002/jmv.10449

30. Tam CC, Rodrigues LC, O'Brien SJ (2003) The study of infectious intestinal disease in England: what risk factors for presentation to general practice tell us about potential for selection bias in case-control studies of reported cases of diarrhoea. Int $\mathrm{J}$ Epidemiol 32:99-105. doi:10.1093/ije/dyg007

31. Sinclair MI, Hellard ME, Wolfe R et al (2005) Pathogens causing community gastroenteritis in Australia. J Gastroenterol Hepatol 20:1685-1690. doi:10.1111/j.1440-1746.2005.04047.x

32. Anderson EJ, Weber SG (2004) Rotavirus infection in adults. Lancet Infect Dis 4:91-99. doi:10.1016/S1473-3099(04)00928-4

33. Wyatt RG, Dolin R, Blacklow NR et al (1974) Comparison of three agents of acute infectious nonbacterial gastroenteritis by cross-challenge in volunteers. J Infect Dis 129:709-714 
34. Parrino TA, Schreiber DS, Trier JS et al (1977) Clinical immunity in acute gastroenteritis caused by Norwalk agent. N Engl J Med 297:86-89

35. De Vos B, Vesikari T, Linhares AC et al (2004) A rotavirus vaccine for prophylaxis of infants against rotavirus gastroenteritis. Pediatr Infect Dis J 23:S179-S182. doi:10.1097/01.inf.0000142370.16514.4a

36. Dennehy PH (2005) Rotavirus vaccines: an update. Curr Opin Pediatr 17:88-92. doi:10.1097/01.mop.0000147907. 30720.04
37. de Quadros CA, Santos JI (2004) Rotavirus: the search for the next generation vaccine. Pediatr Infect Dis J 23:S147-S148. doi:10.1097/01.inf.0000142520.93839.97

38. Lopman BA, Reacher MH, Vipond IB et al (2004) Epidemiology and cost of nosocomial gastroenteritis, Avon, England, 20022003. Emerg Infect Dis 10:1827-1834

39. Gauci C, Gilles H, O'Brien S et al (2007) General practitioners role in the notification of communicable diseases - study in Malta. Euro Surveill 12(11):E5-E6 